\title{
Epidemiology of $\mathrm{X}$-cell gill disease in common dab Limanda limanda
}

\author{
Stig Mellergaard ${ }^{1, *}$, Else Nielsen $^{2}$ \\ ${ }^{1}$ Danish Institute for Fisheries Research, Department for Marine and Coastal Zone Ecology, Fish Disease Laboratory, \\ Bülowsvej 13, DK-1870 Frederiksberg C, Denmark \\ ${ }^{2}$ Danish Institute for Fisheries Research, Department for Marine and Coastal Zone Ecology, Charlottenlund Castle, \\ DK-2920 Charlottenlund, Denmark
}

\begin{abstract}
An epidemiological study of X-cell gill disease in common dab Limanda limanda L. was conducted at a series of stations in the eastern North Sea, the Skagerrak and the Kattegat during the period 1986 to 1993. At most of the stations the prevalence of X-cell gill disease varied from 0 to $1 \%$ throughout the whole period of investigation, except at 3 stations where high prevalences, up to $38 \%$, were observed. Spatial and temporal variations of prevalence were observed. On one occasion it was possible to separate a highly affected dab population from a significantly less affected population within a distaxce of $500 \mathrm{~m}$. This significant spatial variation was not found for the diseases lymphocystis, epidermal papilloma and skin ulcers. At one station the relative risk of contracting $\mathrm{X}$-cell gill disease was significantly higher in female dab compared to males while the opposite was the case at the 2 other stations. X-cell gill disease mainly affected 2 and 3 yr old dab and had a serious effect on the condition of the fish. The condition factor of affected fish was significantly lower compared to healthy specimens. It was not possible to prove an increased mortality in infected fish, although their general condition was extremely poor.
\end{abstract}

KEY WORDS: X-cell gill disease - Dab Limanda limanda - Epidemiology · Low condition factor - Mortality

\section{INTRODUCTION}

For the last 15 yr fish disease investigations have regularly been carried out in the North Sea (Möller 1981, Bucke et al. 1983, Dethlefsen 1984, Mellergaard \& Nielsen 1984, Banning 1987, McVicar et al. 1988). These investigations have dealt mainly with externally visible diseases such as lymphocystis, epidermal papilloma and ulcerations, but some authors (Dethlefsen 1984, McVicar et al. 1988) also reported observations of severely swollen, pale gills in dab-a condition called X-cell gill disease, based on the presence of socalled X-cells in the gill tissue (McVicar et al. 1987). A more generalized condition of this disease has been described by Diamant \& McVicar (1987). Additionally, $\mathrm{X}$-cells have been observed associated with epidermal tumours in flatfish (Brooks et al. 1969, Peters et al.

•E-mail: stig.mellergaard@vetmi.kvl.dk
1978, Peters \& Watermann 1979) and pseudobranchial tumours in cod (Alpers et al. 1977, Morrison et al. 1982, Watermann \& Dethlefsen 1982).

Reports on the spatial distribution of $\mathrm{X}$-cell gill disease in dab in the North Sea have focussed on the central and southern parts (Knust \& Dethlefsen 1986 , McVicar et al. 1987, Diamant \& McVicar 1989), and the results of these studies demonstrate a certain patchiness of the distribution of the disease.

The endemic occurrence of X-cell disease in most of the North Sea combined with certain epidemic situations indicates that the disease has an infectious background, although the exact etiology has not yet been identified. Some studies suggest that $\mathrm{X}$-cells are protozoan parasites (Dawe et al. 1979, Watermann \& Dethlefsen 1982, Harshbarger 1984).

The present work describes the epidemiology of Xcell gill disease in dab in the eastern part of the North Sea and the Skagerrak, and concentrates on 3 areas where the disease occurred in high prevalences. 


\section{MATERIALS AND METHODS}

Fish sampling. Common dab Limanda limanda L. were sampled annually in May from 1986 to 1993 on board the RV 'Dana' using a standard Nymplex fishing trawl, 'Star' model. The trawl was rigged either with 12" $(30 \mathrm{~cm})$ rubber discs or with $10^{\prime \prime}(25 \mathrm{~cm})$ bobbins on the foot rope-depending on the bottom conditions in the area of research - and fitted with a foot rope chain. The stretched mesh size in the cod end was $40 \mathrm{~mm}$. Fishing took place at a number of sites where trawl tracks were available from commercial fishermen (Fig. 1). Hauls of $1 \mathrm{~h}$ were taken at a speed of 3 knots. Normally 1 or 2 hauls were taken at each station, except on special occasions when fishing took place in a grid pattern as descrubed in 'Results: Spatial variations'.

Handling of the sample. The total catch was sorted into species and the dabs were subjected to further investigation. A sample of 150 to 250 specimens [a sample size required for the detection of a prevalence of at least $2 \%$ with $95 \%$ confidence (Martin et al. 1987)] corresponding to 15 to $20 \mathrm{~kg}$ per haul was examined. Subsamples were taken at random if the total weight of dabs exceeded $20 \mathrm{~kg}$. For all fish examined, the length, weight, sex and health status were registered. The otoliths were removed from the first 96 fish for ageing.

Selection of gross lesions. The dabs were examined for the presence of the diseases lymphocystis, epidermal hyperplasia/papilloma, skin ulcers and X-cell gill disease using recommended procedures for detection (Anonymous 1989). These diseases have been well described in the literature (Möller \& Anders 1983, Bucke et al. 1995) in terms of their gross appearance and etiology.

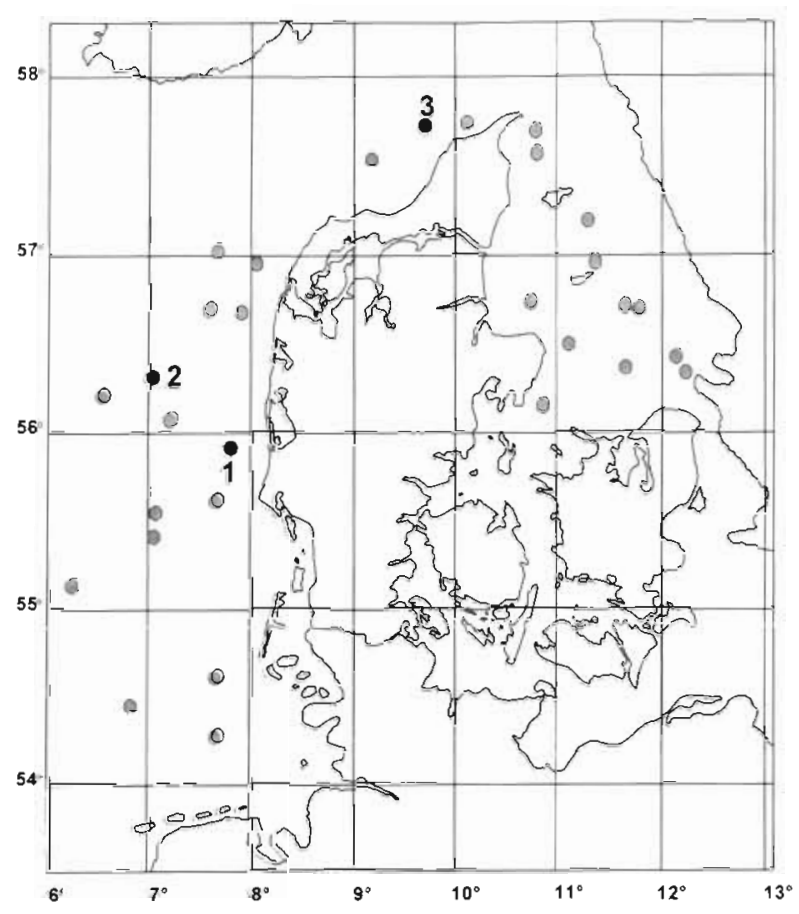

Fig. 1. Stations around Denmark visited during this fish disease survey. The black and numbered localities represent the 3 stations with high prevalence of $\mathrm{X}$-cell gill disease in dab

Fish affected by $\mathrm{X}$-cell disease are generally emaciated with slightly elevated operculum. The gills are pale. The gill lamellae are swollen and appear light pink in moderate cases while creamy white in severe cases (Fig. 2). X-cell gill disease was registered from 1986 onwards

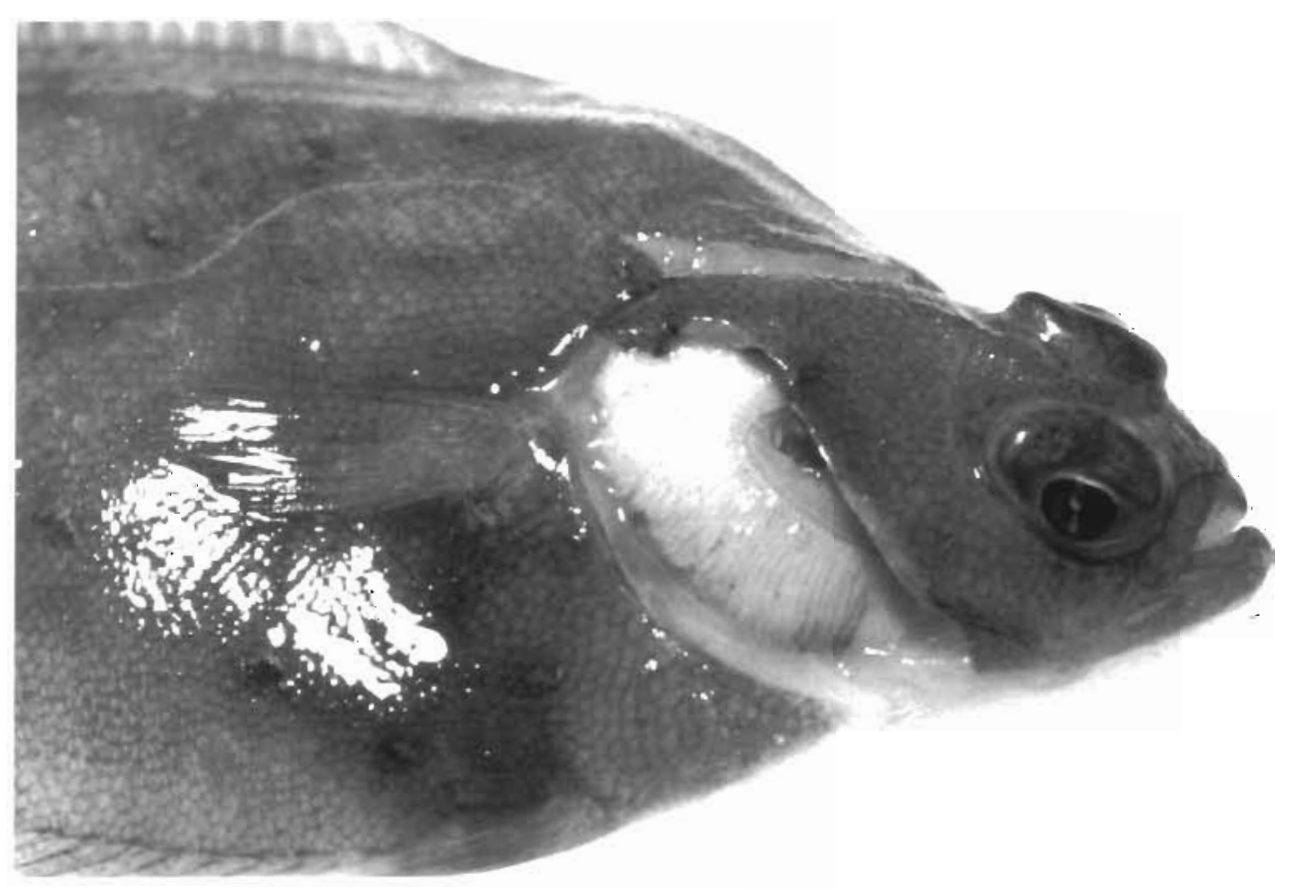

Fig. 2. Limanda limanda. $X$-cell gill disease affected dab. Notice the swollen and pale gill lamellae 
Macroscopic inspection. The macroscopic inspection was carried out according to the recommendations in Anonymous (1989). In order to obtain the highest degree of precision in the diagnostics of the diseases, only 1 person conducted the registration during the whole period of the investigation. The otoliths were read by 2 skilled peoples.

Data analysis. Most of the data analyses were carried out using the public domain software 'Epi Info' version 5.0 (Dean et al. 1990) and Statistix, version 4.1 (Analytical Software). The strength of association between a 'factor' and a disease is known as the relative risk (RR). The $\mathrm{RR}$ is the ratio between the disease rate in an 'exposed' group and the disease rate in an 'unexposed' group and is presented with $95 \%$ confidence intervals. The RR in an 'exposed' group is significantly different from the RR in an 'unexposed' group if the confidence interval for RR does not encompass the value 1 .

The statistical tests applied for the data treatment were chi-square test, 2-sample t-test and Mann-Whitney rank test. To test for difference between the slopes of 2 regression lines a modified $t$-test was used (Zar 1984).

The condition factor $\left[100 \times\right.$ weight $(\mathrm{g}) \times$ length $\left.^{-3}(\mathrm{~cm})\right]$ was calculated based on the total weight of individual fish (in contrast to gutted weight as recommended in Anonymous 1989).

\section{RESULTS}

The intensity of the gill lesions ranged from a few swollen lamellae on 1 gill arc to extreme conditions with all gill lamellae affected to a degree where the tips of the lamellae protuded as a creamy white band outside the opercular edge, with the latter being the predominant finding.

The prevalence of X-cell gill disease showed considerable spatial and temporal variation. At most of the stations the prevalence varied from 0 to $1 \%$ throughout the whole period of investigation, except at the 3 stations marked in Fig 1 where prevalences up to $38 \%$ were observed.

The total number of dab and X-cell gill disease affected fish separated by sex and year and the mean prevalence of the disease for each hot-spot station are presented in Table 1. With regard to the total number of fish examined, an even sexual distribution was observed at Stn 1 while at Stns 2 and 3, a significantly higher number of females ( $p<0.001)$ was present in the catches.

\section{Temporal variations}

At Stn 1 the prevalence ranged from 2.6 to $36.6 \%$ while the range for $\operatorname{Stn} 2$ was from 0.0 to $10.4 \%$. For both

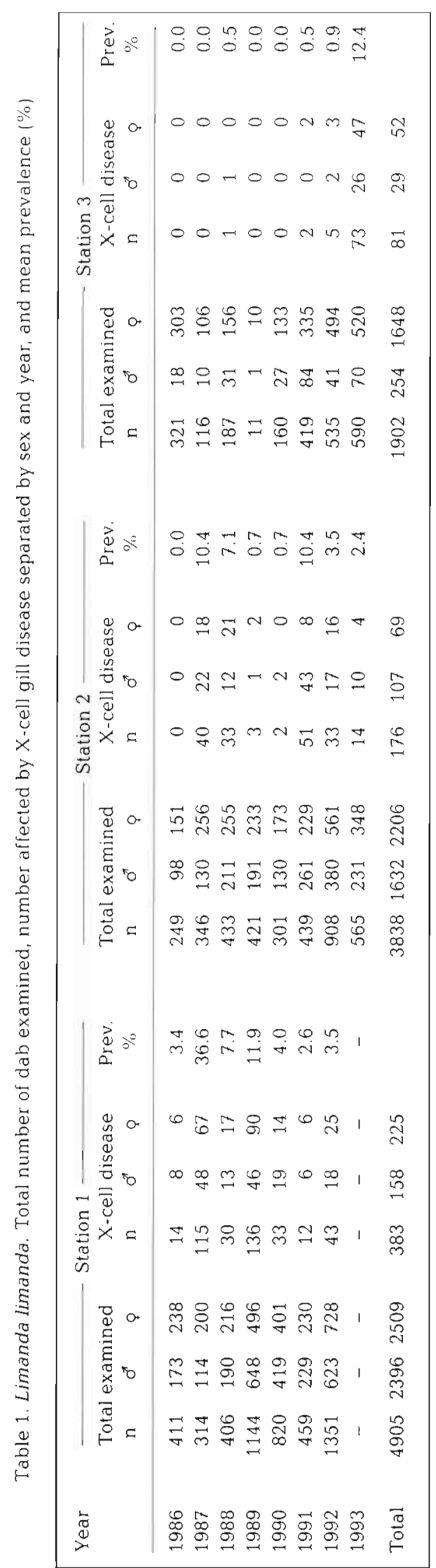


these stations large temporal variations were observed. In contrast to Stns 1 and 2, the prevalence at Stn 3 was at a low level, from 0.0 to $0.9 \%$, in the period from 1986 to 1992, while it increased to more than 12\% in 1993.

The relative risk (RR) of contracting $X$-cell gill disease at the 3 stations is illustrated in Fig 3. For Stn 1, the RR relative to 1986 (taken here as the 'unexposed' group) was significantly higher from 1987 to 1989 while no significant difference was observed in the period 1990 to 1992 . For Stn 2, the RR was calculated based on the 1987 figures as the prevalence of X-cell gill disease in 1986 was zero. The risk in 1988 and 1991 was not significantly different from 1987 while it was
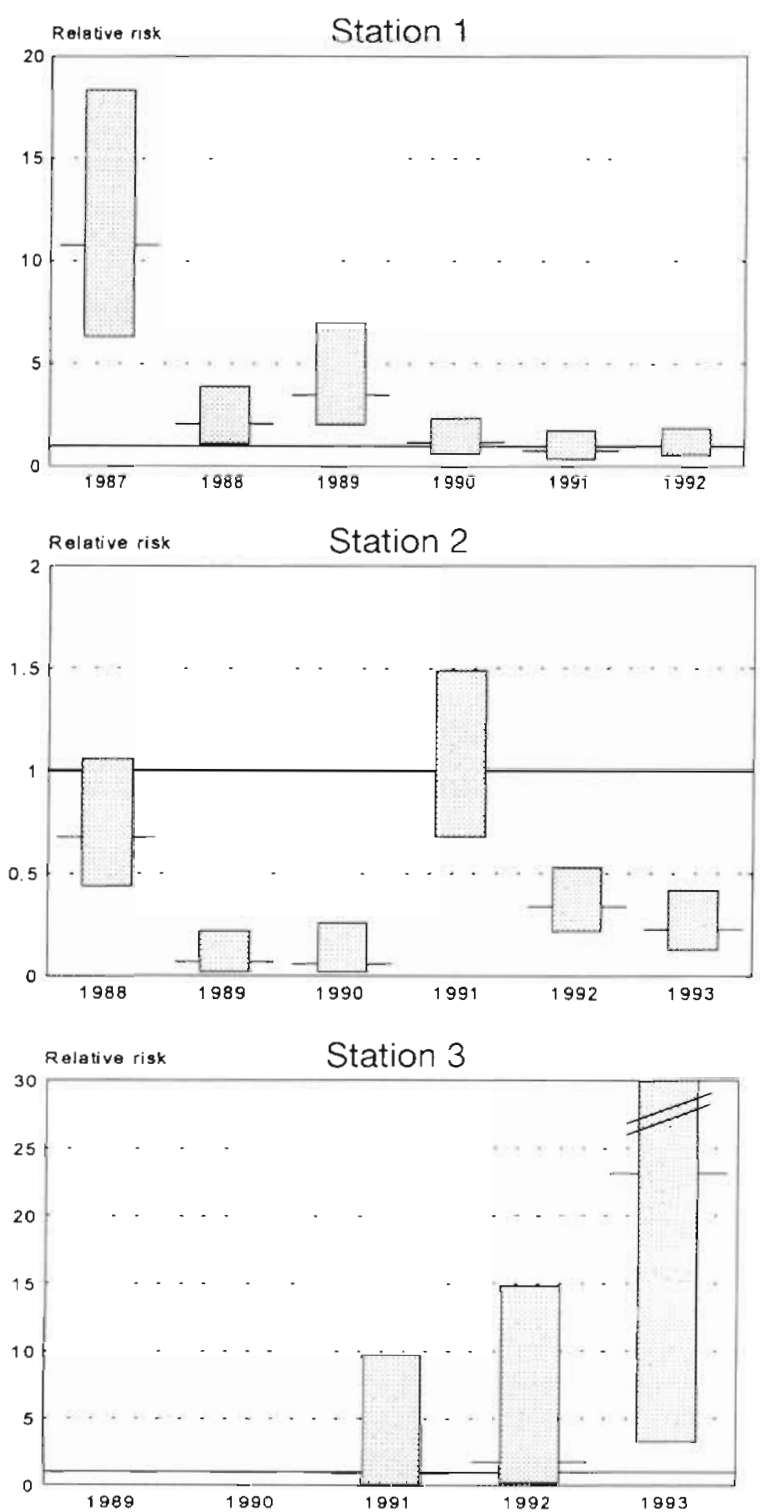

Fig. 3. Limanda limanda. Relative risk of $X$-cell gill disease in dab at the 3 hot-spot stations; the tick mark indicates the relative risk and the bar the confidence interval
Table 2. Limanda Limanda. Prevalence (\%) of X-cell gill disease in different hauls at Stn 1

\begin{tabular}{|c|c|c|c|c|c|c|}
\hline \multirow[t]{2}{*}{ Year } & \multicolumn{6}{|c|}{ Haul } \\
\hline & A & B & $\mathrm{C}$ & $\mathrm{D}$ & E & $\mathrm{F}$ \\
\hline 1986 & 0.0 & 6.7 & & & & \\
\hline 1.987 & 35.6 & 38.0 & & & & \\
\hline 1988 & 3.1 & 10.8 & & & & \\
\hline 1989 & 15.9 & 5.3 & 11.2 & 1.8 & 23.3 & 2.5 \\
\hline 1990 & 3.5 & 4.7 & 3.5 & & & \\
\hline 1991 & 3.5 & 1.5 & & & & \\
\hline 1992 & 1.7 & 2.8 & 5.1 & 5.3 & 3.9 & \\
\hline
\end{tabular}

significantly lower in 1989 and 1990, and in 1992 and 1993. At Stn 3, the disease was not observed until 1988 , hence this year was applied as baseline year. The RR iri 1989 and 1990 was zero due to no observed cases and in 1991 and 1992 the risk was not significantly different from 1988. In 1993, the RR was significantly higher than in 1988.

\section{Spatial variations}

Besides the observed temporal variations in the prevalence of $X$-cell gill disease at Stn 1, large haul-tohaul variations also occurred in some years, e.g. 1988 (Table 2). In order to investigate this variation, the

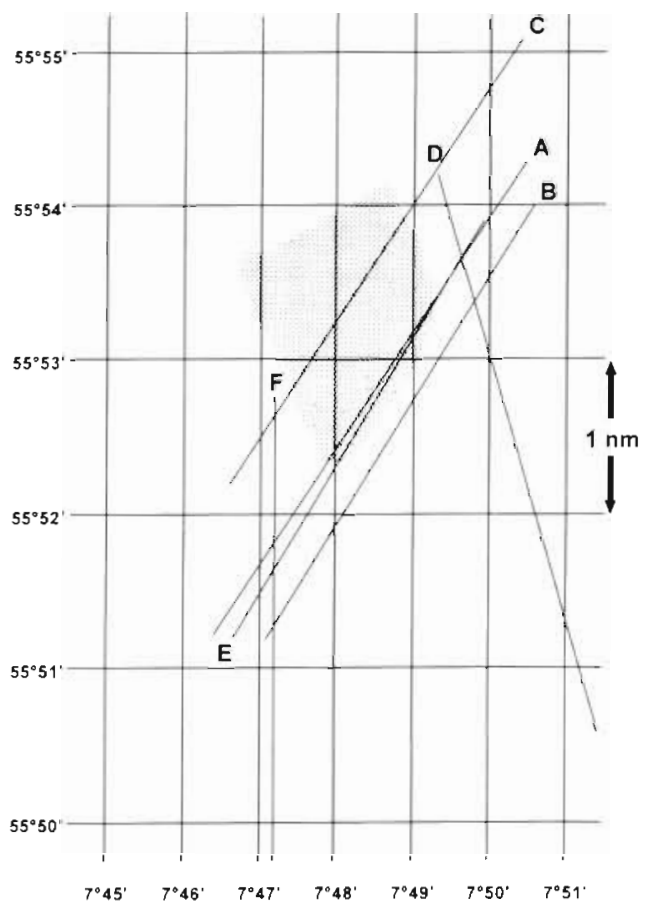

Fig. 4. Trawl tracks used in 1989 to investigate the spatial distribution of X-cell gill disease in dab at Stn 1. Dotted area indicates the possible distribution of a severoly affected dab population 

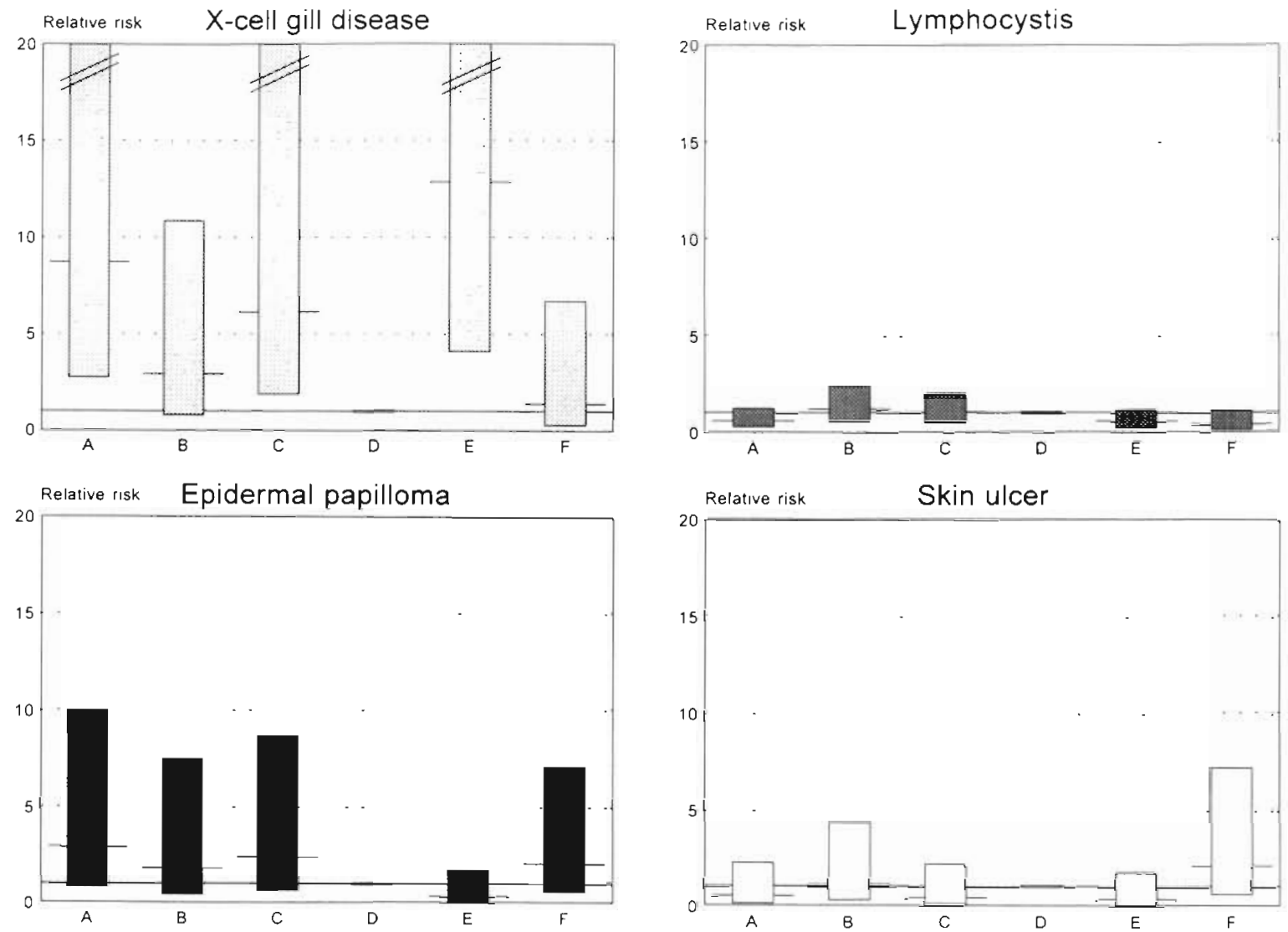

Fig. 5. Limanda limanda. Relative risk of X-cell gill disease, lymphocystis, epidermal papilloma and skin ulcers for dab collected along 6 trawl tracks at Stn 1 in 1989

trawling was carried out in a grid-like pattern in 1989 as illustrated in Fig. 4. This experiment showed high prevalence of X-cell gill disease in 3 of the 6 trawl tracks as listed in Table 2. Fig. 5 illustrates the relative risk of X-cell gill disease, lymphocystis, epidermal papilloma and skin ulcers observed in the different hauls in 1989. All calculations were made relative to haul D which had the lowest prevalence. The relative risk of contracting $\mathrm{X}$-cell gill disease was significantly higher on tracks $A, C$ and $E$, ranging from 6.1 to 12.8

Table 3. Limanda limanda. Prevalence (\%) of X-cell gill disease in different hauls at Stn 2

\begin{tabular}{|rrrrr|}
\hline Year & \multicolumn{4}{c|}{ Haul } \\
& A & \multicolumn{1}{c|}{ B } & C & D \\
\hline 1986 & 0.0 & 0.0 & & \\
1987 & 10.5 & 10.3 & & \\
1988 & 7.3 & 6.8 & & \\
1989 & 0.9 & 0.5 & & \\
1990 & 0.7 & & & \\
1991 & 10.0 & 10.8 & & 4.7 \\
1992 & 3.9 & 1.6 & 4.1 & 4 \\
1993 & 2.3 & 2.6 & & \\
\hline
\end{tabular}

( $p<0.001$ ), while the risk on tracks $B$ and $F$ did not differ significantly from track D. The other investigated diseases did not show similar significantly higher relative risks in tracks $A, C$ and $E$ compared with $D$ as observed for X-cell gill disease.

In contrast to $\operatorname{Stn} 1$, Stn 2 revealed minimal haul-tohaul variations (Table 3 ). The prevalence of $\mathrm{X}$-cell disease at $\operatorname{Stn} 3$ was low until it appeared with high prevalence in 1993. In that year, a marked haul-to-haul variation was observed (Table 4).

Table 4. Limanda limanda. Prevalence (\%) of X-cell gill disease in different hauls at Stn 3

\begin{tabular}{|ccc|}
\hline Year & \multicolumn{3}{c|}{ Haul } \\
& A & B \\
\hline 1986 & 0.0 & 0.0 \\
1987 & 0.0 & 0.0 \\
1988 & 1.9 & 0.0 \\
1989 & 0.0 & \\
1990 & 0.0 & \\
1991 & 0.9 & 0.0 \\
1992 & 1.5 & 0.4 \\
1993 & 7.6 & 16.2 \\
\hline
\end{tabular}


Station 1

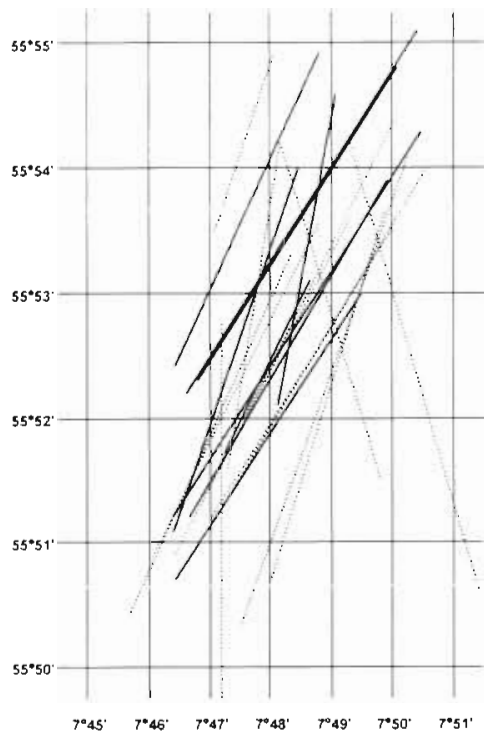

Station 2

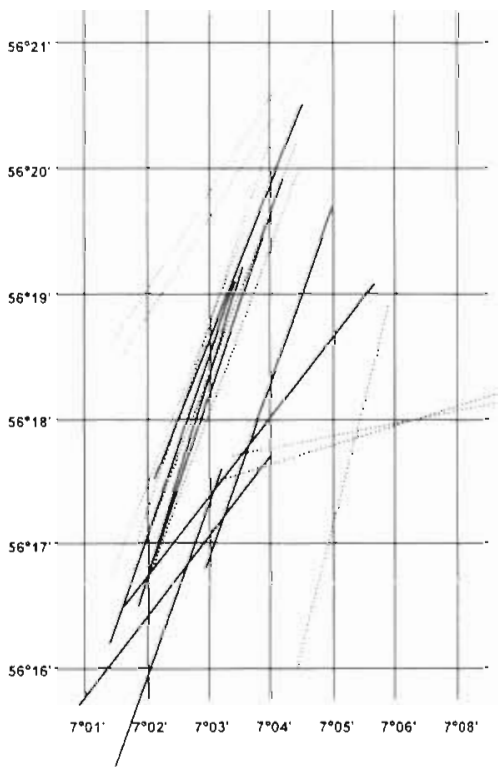

Station 3

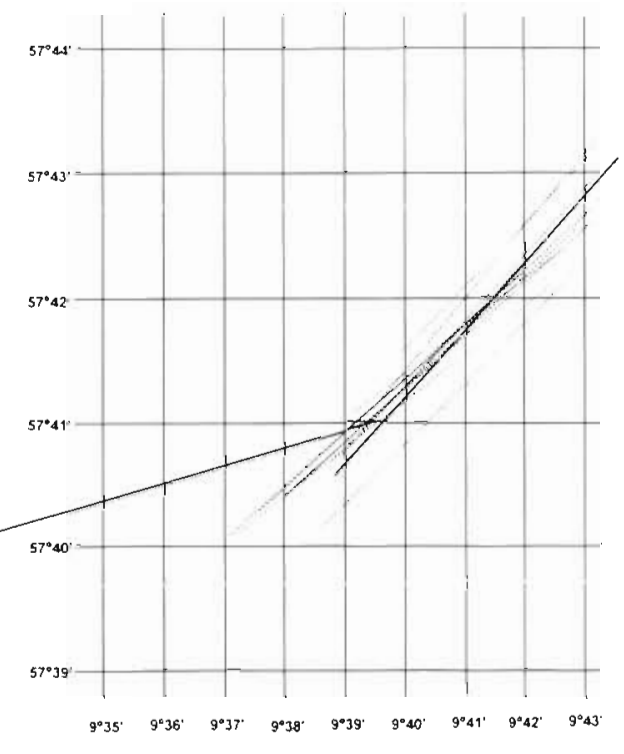

Fig. 6. Trawl tracks taken throughout the period 1986 to 1993 at the 3 hot-spot stations. Solid line indicates a prevalence of X-cell gill disease above $4 \%$ and dotted line a prevalence below $4 \%$

Fig. 6 illustrates the trawl tracks taken at each station throughout the period of the investigation. All tracks were taken within an area of approximately $4 \times 3$ nautical miles $(7.5 \times 5.5 \mathrm{~km})$. Full lines indicate that samples caught in these hauls had a prevalence of X-cell gill disease above $4 \%$ while dotted lines indicate a prevalence below this level. At Stns 1 and 2,
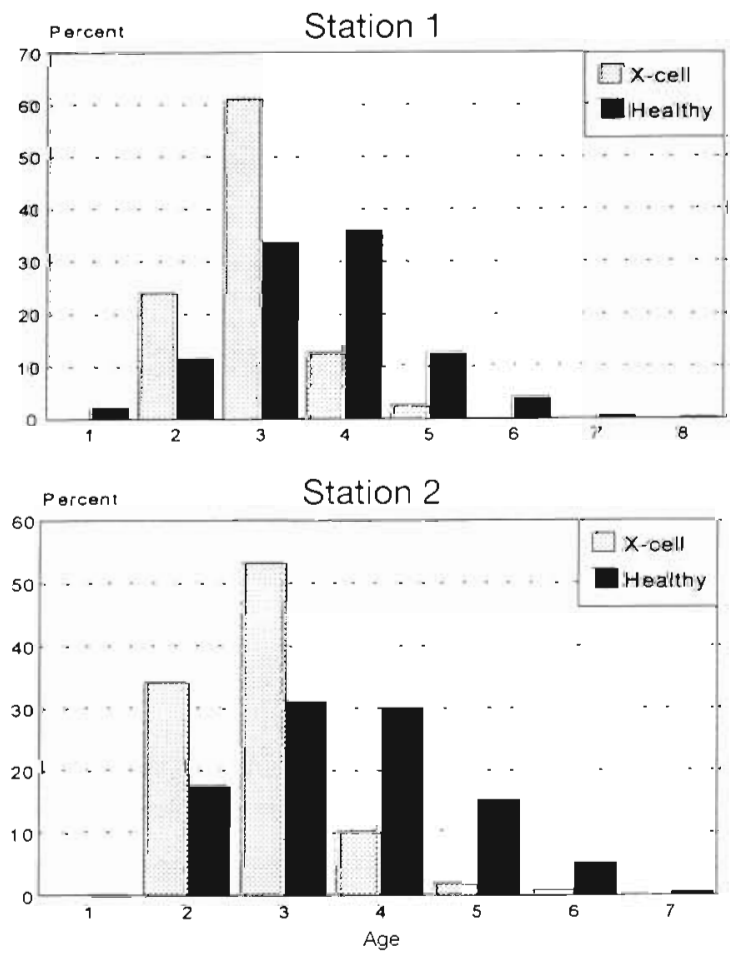

there exists no clear trend in the patchy distribution of high prevalences (>4\%) of X-cell gill disease, although there may be a tendency towards concentration in the central parts of those areas. For Stn 3, the prevalence of X-cell gill disease was below $4 \%$ until 1993. In that year, the haul with the highest prevalence (16.2\%) was the one that diverged from the main track area.

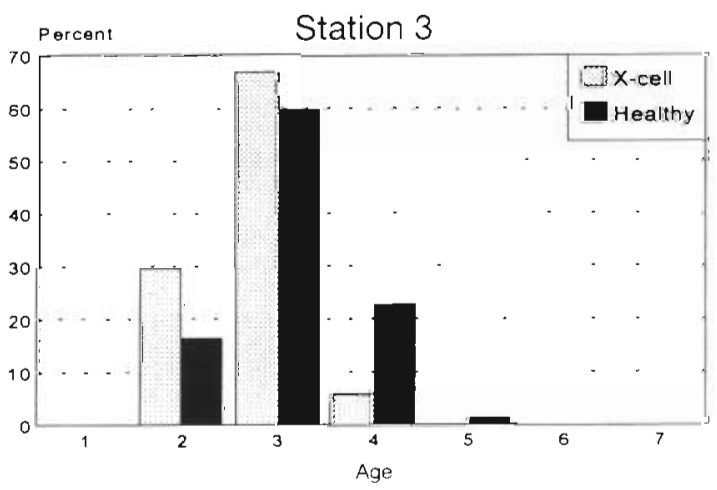

Fig. 7. Limanda limanda. Age composition of X-cell gill disease for affected and healthy dab at Stns 1,2 and 3. Dab aged 2 and 3 yr are the predominant age groups afferted by the disease 

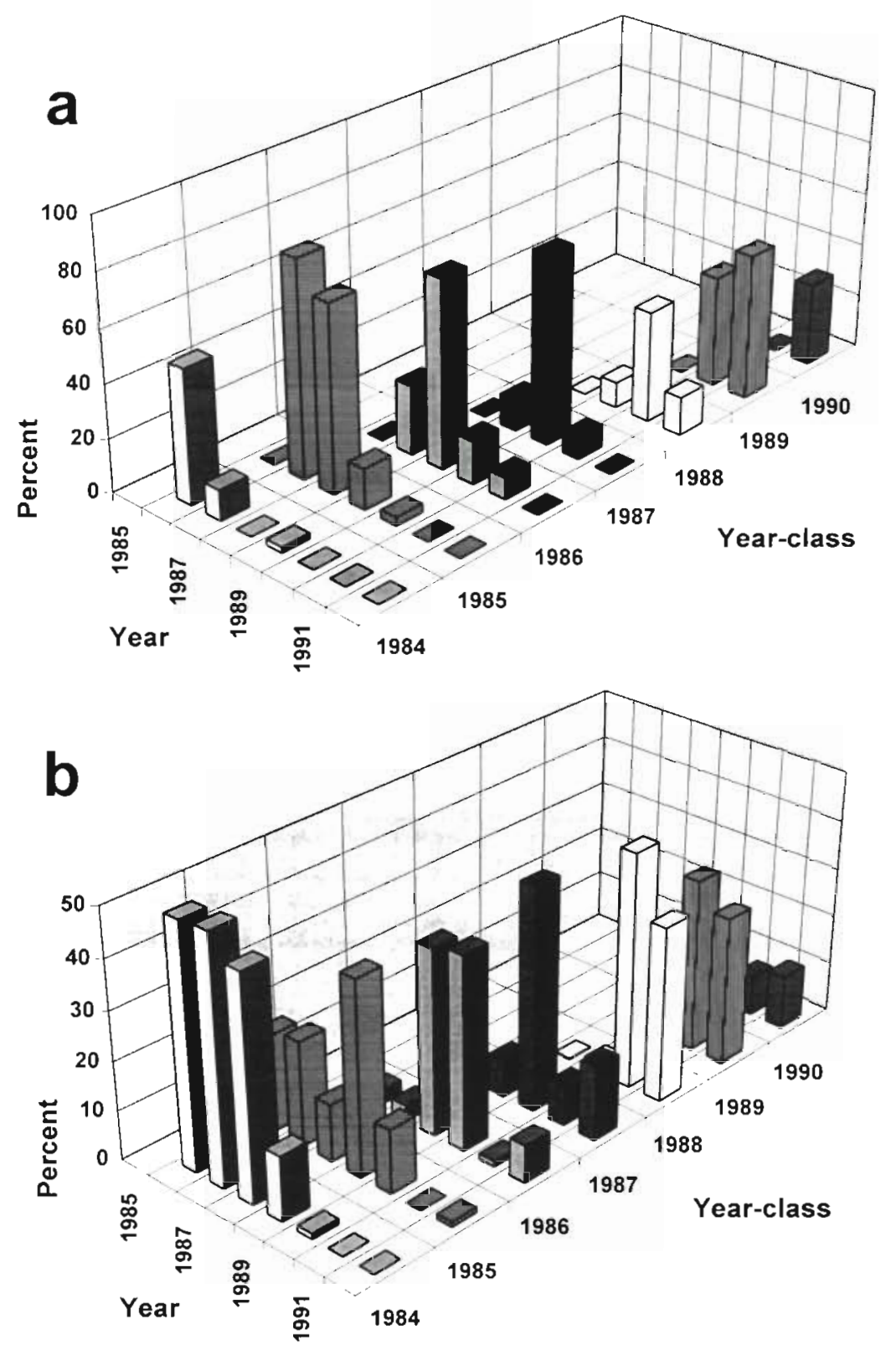

Fig. 8. Limanda limanda. Age composition of the different year-classes (cohorts) of (a) X-cell gill disease affected, and (b) healthy dab at Stn 1
At Stn 2, the age distribution of both the affected and healthy fish was very similar to that observed at Stn 1, with the most severely affected age groups being the 2 and 3 yr old fish. The age range for the $\mathrm{X}$-cell affected dab was 2 to 6 yr while the healthy fish were within the age groups 1 to $7 \mathrm{yr}$. The healthy fish had a significantly higher mean age $(3.6 \mathrm{yr})(\mathrm{p}<0.001)$ compared to the $X$-cell affected fish $(2.8 \mathrm{yr})$.

At Stn 3, the age structure of the healthy dab was more narrowly concentrated around the 3 yr old fish in comparison to Stns 1 and 2. Similar to those 2 stations, the mean age of the healthy group was significantly higher (3.1 yr) $(p<0.05)$ than for the affected fish (2.8 yr).

The age structure of each year-class (cohort) is illustrated in Fig. 8 for the diseased and healthy dab at Stn 1 . It displayed a similar structure from year to year with a peak for affected fish at an age of 2 to 3 yr while 3 and 4 yr old fish were predominant in the healthy group.

The regression lines for the abundance $[(l n+1)$ transformed] relative to age of the affected and unaffected dab were calculated (Fig. 9) to assess whether X-cell gill disease caused increased mortality in the affected stock compared with the healthy population. The slope of the regression line for the affected fish was steeper than for the unaffected stock, suggesting an increased mortality due to the disease. However, a test for equality of the slopes of the 2 lines did not show a statistically significant difference between the age-related decline of the 2 groups.

\section{Effect on age structure}

The age structure of the healthy and X-cell disease affected dab stock is illustrated in Fig. 7. At Stn 1, Xcell gill disease was observed in age groups 2 to $5 \mathrm{yr}$, mainly affecting the 2 and 3 yr old fish, while the age of the healthy group ranged from 1 to $8 \mathrm{yr}$. The mean age was significantly higher $(3.6 \mathrm{yr})(\mathrm{p}<0.001)$ in the healthy population compared to the $\mathrm{X}$-cell disease affected stock (2.9 yr) (Mann-Whitney rank test).

\section{Effect on growth}

Healthy fish were significantly longer ( $p<0.0001$ ) than affected specimens at both Stns 1 and 2 (MannWhitney rank test). The mean length of diseased dab was $13.6 \mathrm{~cm}$ (range 8 to $23 \mathrm{~cm}$ ) compared to $16.8 \mathrm{~cm}$ (range 6 to $40 \mathrm{~cm}$ ) for unaffected fish at $S \operatorname{tn} 1$, and $13.7 \mathrm{~cm}$ (range 9 to $26 \mathrm{~cm}$ ) compared to $17.0 \mathrm{~cm}$ (range 7 to $33 \mathrm{~cm}$ ) at Stn 2. In contrast, the affected fish at Stn 3 were longer, with a mean length of $18 \mathrm{~cm}$ (range 12 to $25 \mathrm{~cm}$ ) compared to $17.4 \mathrm{~cm}$ (range 8 to $29 \mathrm{~cm}$ ), 


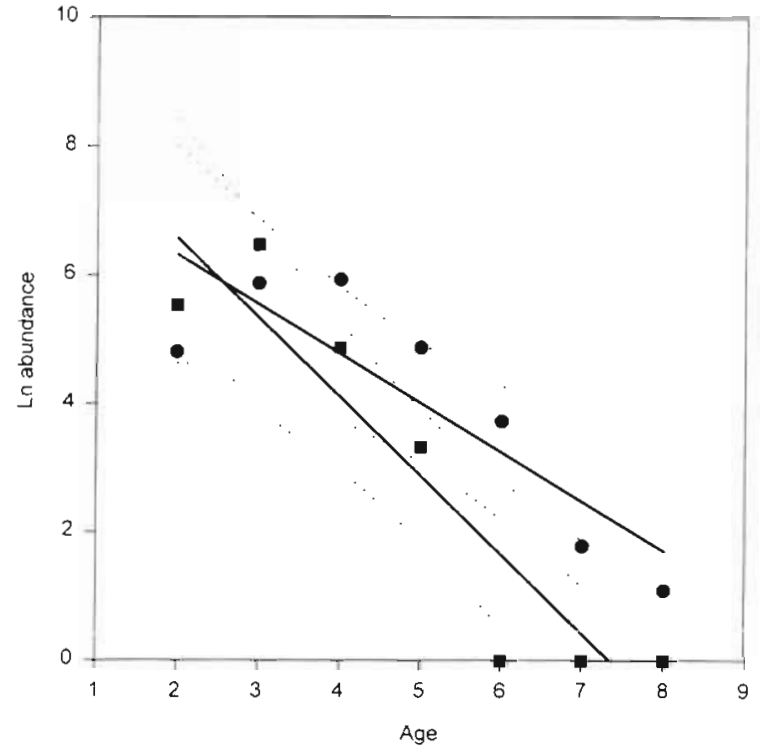

Fig. 9. Ln abundance per age group of healthy ( $\bullet$; upper regression line with $95 \%$ confidence interval) and X-cell

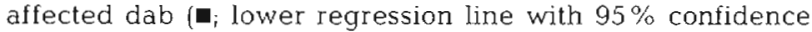
interval). The regression line for the $\mathrm{X}$-cell affected population has a steeper slope than the one for the healthy population, suggesting an increased mortality in the affected dab

for the unaffected fish, but these figures were not significantly different.

Table 5 presents the length data stratified by age. At Stn 1, the healthy 3,4 and 5 yr old fish were significantly longer than the X-cell affected ones $(p<0.005)$ while no significant difference was observed in the 2 yr old fish. At Stn 2, only the 3 yr old healthy fish were significantly longer $(\mathrm{p}<0.005)$ than the $\mathrm{X}$-cell affected ones. No significant differences between the mean lengths of any of the age groups was observed at Stn 3.

\section{Effect on condition factor}

A common feature of all 3 stations was that the condition factor of affected dab was significantly lower ( $p$ $<0.001$ ) than that of unaffected fish ( $t$-test) (Table 6$)$. The condition factor of healthy and diseased fish stratified by sex was significantly different $(p<0.001)$ for both males and females.

As the X-cell disease seemed to have an effect on the growth of the fish, subsamples of affected and unaffected fish of approximately equal length $(13 \mathrm{~cm})$ were analysed in order to assess the effect of the disease on age structure, weight and condition factor. The key values appear in Table 7. Differences were observed between the mean weight and the mean condition factor of
Table 5. Limanda limanda. Mean length $(\mathrm{cm})$ for X-cell gill disease affected and healthy dab separated by age. $p<0.005$

\begin{tabular}{|c|c|c|c|c|}
\hline Age $(y r)$ & & $\operatorname{Stn} 1$ & Stn 2 & $\operatorname{Stn} 3$ \\
\hline 2 & $\begin{array}{l}\text { Healthy } \\
\text { X-cell }\end{array}$ & $\begin{array}{l}12.71 \\
12.50\end{array}$ & $\begin{array}{l}12.82 \\
12.41\end{array}$ & $\begin{array}{l}14.79 \\
15.90\end{array}$ \\
\hline 3 & $\begin{array}{l}\text { Healthy } \\
\text { X-cell }\end{array}$ & $\begin{array}{l}15.86^{\circ} \\
13.88^{\circ}\end{array}$ & $\begin{array}{l}16.06^{\circ} \\
14.72\end{array}$ & $\begin{array}{l}17.80 \\
17.36\end{array}$ \\
\hline 4 & $\begin{array}{l}\text { Healthy } \\
\text { X-cell }\end{array}$ & $\begin{array}{l}19.35^{\circ} \\
15.39\end{array}$ & $\begin{array}{l}19.26 \\
16.33\end{array}$ & $\begin{array}{l}20.49 \\
14.50\end{array}$ \\
\hline 5 & $\begin{array}{l}\text { Healthy } \\
\text { X-cell }\end{array}$ & $\begin{array}{l}22.00^{\circ} \\
19.14\end{array}$ & $\begin{array}{l}21.35 \\
19.0\end{array}$ & \\
\hline
\end{tabular}

Table 6. Limanda limanda. Mean condition factor for X-cell gill disease affected and healthy dab separated by sex. ${ }^{*} p<0.001$

\begin{tabular}{|c|c|c|c|c|}
\hline Sex & & Stn 1 & Stn 2 & Stn 3 \\
\hline $0^{x}$ & $\begin{array}{l}X \text {-cell } \\
\text { Healthy }\end{array}$ & $\begin{array}{l}0.846^{\circ} \\
0.934\end{array}$ & $\begin{array}{l}0.890^{\circ} \\
0.973\end{array}$ & $\begin{array}{l}0.920^{\circ} \\
0.992\end{array}$ \\
\hline 9 & $\begin{array}{l}\text { X-cell } \\
\text { Healthy }\end{array}$ & $\begin{array}{l}0.874 \\
0.963\end{array}$ & $\begin{array}{l}0.8722^{\circ} \\
1.000\end{array}$ & $\begin{array}{l}0.913^{\circ} \\
1.016\end{array}$ \\
\hline Total & $\begin{array}{l}X \text {-cell } \\
\text { Healthy }\end{array}$ & $\begin{array}{l}0.859^{\circ} \\
0.951\end{array}$ & $\begin{array}{l}0.883^{\circ} \\
0.990^{\circ}\end{array}$ & $\begin{array}{l}0.915^{\circ} \\
1.013^{\circ}\end{array}$ \\
\hline
\end{tabular}

the 2 groups. However, only the mean condition factor was significantly different $(p<0.002, t$-test)

\section{Sex related differences}

At Stn 1 female dab had a significantly higher risk of contracting $\mathrm{X}$-cell disease than males $(\mathrm{RR}=1.36$; $\mathrm{p}<$ $0.002)$. However, the opposite situation was observed at Stns 2 and 3 where female dab had a significantly lower risk of contracting $\mathrm{X}$-cell disease compared to males $(R R=0.48$ and $R R=0.28$, respectively $)(p<0.00001)$.

\section{DISCUSSION}

In Danish coastal areas, $\mathrm{X}$-cell gill disease in common dab occurred at low prevalence except at 3 hotspot stations (Fig. 1). At these stations, considerable variation of the prevalence-spatial as well as tem-

Table 7. Limanda limanda. Mean length, weight, condition factor and age for a subsample of $\mathrm{X}$-cell gill disease affected and healthy dabs

\begin{tabular}{|lccccc|}
\hline & $\mathrm{n}$ & $\begin{array}{c}\text { Mean } \\
\text { length }(\mathrm{cm})\end{array}$ & $\begin{array}{c}\text { Mean } \\
\text { weight }(\mathrm{g})\end{array}$ & $\begin{array}{c}\text { Mean } \\
\text { condition factor }\end{array}$ & $\begin{array}{c}\text { Mean } \\
\text { age }(\mathrm{yr})\end{array}$ \\
\hline X-cell & 26 & 12.56 & 15.60 & 0.7341 & 2.59 \\
Healthy & 22 & 12.94 & 19.23 & 0.8282 & 2.64 \\
\hline
\end{tabular}


poral-ranging from a few percent up to $38 \%$ was observed (Table $1,2 \& 3$ ). Similar patchiness in the distribution of $\mathrm{X}$-cell gill disease has been reported from other areas of the North Sea: the Dogger Bank and the Humber area (Knust \& Dethlefsen 1986, McVicar et al. 1987) and in certain areas along the Scottish east coast (Diamant \& McVicar 1989). However, prevalences higher than $10 \%$ have only been observed in Danish coastal areas and in the southern Moray Firth (Diamant \& McVicar 1989). The present work deals with disease investigations over a period of 7 to 8 yr while formerly published work on X-cell gill disease (Knust \& Dethlefsen 1986, Diamant \& McVicar 1989) dealt with observations over a period of 3 yr. Knust \& Dethlefsen (1986) demonstrated distinct temporal and spatial variations in the prevalence of $X$-cell gill disease in the North Sea. Although they observed hot-spot sites in both the Dogger and Humber regions, these were not at the same positions at each time of year. Diamant \& McVicar (1989) visited the same stations each year from 1985 to 1987 and found a very high prevalence (more than $60 \%$ ) at one station in 2 consecutive years. These authors also observed considerable spatial variations even within relatively short distances just as observed in the present work.

The scenario from Stn 1 in 1989 (Fig. 4) showed that within a distance of about $1 / 4$ nautical mile $(500 \mathrm{~m})$, the distance from haul $\mathrm{A}$ and $\mathrm{E}$ to haul $\mathrm{B}$, the prevalence varied significantly from approximately 20 to $5 \%$ (Table 2). Based on the 6 hauls taken there in 1989, it was possible to frame a high prevalence area (Fig. 4, dotted area) within very narrow limits. The relative risk of lymphocystis, epidermal papilloma and skin ulcers within the different hauls did not differ significantly. However, the observation of a seriously X-cell affected population being separated from a significantly less affected population within a distance of $500 \mathrm{~m}$ gives an impression of the severity of the disease. The gill lesions probably debilitate the fish to a degree where they are unable to travel over longer distances due to respiratory constraint. The impact of the disease was also reflected in the significantly lower condition factor of affected dab compared to that of unaffected fish, whether considering all fish examined, fish separated by sex, or fish within the same length group. This clear difference in the condition factor between affected and unaffected fish was only partly reflected in the observations of Knust \& Dethlefsen (1986). In general, these authors found that the condition factor of affected fish was reduced compared to healthy specimens and that this difference was found to be statistically significant regarding the males but only sporadically significant for the females.

The present study showed that mainly the young age groups became infected with $X$-cell gill disease. The mean age of affected dab at the 3 hot-spot areas ranged from 2.8 to $2.9 \mathrm{yr}$ while the mean age for the healthy population was between 3.1 and $3.6 \mathrm{yr}$ This pattern was repeated for each year-class (cohort) at Stn 1 throughout the whole study period as illustrated in Fig. 8. This corresponds with the observations of Knust \& Dethlefsen (1986) who found X-cell affected fish within the age range of 2 to 5 yr in contrast to the healthy fish which were represented within the age group 3 to $7 \mathrm{yr}$.

The length distribution of affected fish differed among the 3 stations. At Stns 1 and 2, the mean length of affected fish was approximately $14 \mathrm{~cm}$ while at Stn 3 it was $18 \mathrm{~cm}$, although identical age groups were affected. A possible explanation for this difference is that we may be dealing with 2 different dab stocks which have different growth rates, as proposed by Mellergaard \& Nielsen (1984). Differences in the length distribution of $X$-cell affected fish between the present study and others (Knust \& Dethlefsen 1986, Diamant \& McVicar 1989) may be attributed to different growth rates of the affected dab stocks.

The observed difference in the relative risk of $X$-cell gill disease between males and females, with a significantly higher risk for females contracting the disease compared to males at Stn 1, while the opposite situation was true at Stns 2 and 3, has no obvious explanation. Knust \& Dethlefsen (1986), McVicar et al. (1987) and Diamant \& McVicar (1989) did not mention such a phenomenon. It is unlikely that it is due to statistical variability ( $\mathrm{p}<0.005$ ), but from a biological point of view mere variability is a more plausible explanation.

The impact of the disease on growth became apparent in the 3 yr old age group at Stns 1 and 2 (Table 5), indicating that the disease has to be established in the fish for a certain period before growth is seriously reduced. This is supported by the fact that no adverse effect on growth was observed at $\operatorname{Stn} 3$ where the disease had reached epidemic proportions within the previous year. The observation that the same age groups ( 2 and 3 yr old fish) are affected by $X$-cell gill disease in each cohort suggests that the duration of the disease is short, which may be due to either high recovery or high mortality rate. The latter is the most likely explanation. Affected fish have a severely reduced capacity to withstand the stress of capture. Most of these fish die shortly after being brought on deck, probably severely debilitated by respiratory problems as indicated by Diamant \& McVicar (1987). One impact of the disease was a significantly lower condition factor for affected fish than for healthy specimens. Furthermore, there is a significant decline in the prevalence of the disease from age 3 to 4 yr (Fig. 7) and, although not statistically significantly different, the plots of the regression lines for the abundance at age of healthy and diseased dab 
(Fig. 8) showed a steeper slope for the X-cell affected fish, indicating higher mortality in this group than in the healthy population. Taking these factors in consideration, it is likely that X-cell gill disease is fatal for affected dab, although Diamant \& McVicar (1987) recorded that recovery may occur in some cases. Mortality in fish due to conditions where $X$-cells have been involved has previously been described in starry flounder Platichthys stellatus with skin tumours (Campana 1982).

The epidemiological data on X-cell gill disease presented in this study showing temporal and spatial fluctuations clearly add to previous suggestions (McVicar et al. 1987, Diamant \& McVicar 1989) that the disease has an infectious etiology. The background for the shifts in the epidcmiological status of $\mathrm{X}$-cell gill disease in certain areas e.g. from endemic to epidemic situations can only be explained by either changes in the virulence of the possible infectious agent or changes in the immunological status of the local dab populations.

Acknowledgements. We thank Ms Inger Hornum for excellent technical assistance and the crew of RV 'Dana' for excellent collaboration during the surveys.

\section{LITERATURE CITED}

Alpers CE, Cain BB, Myers $M$, Wellings SR, Poore M, Bagshaw J, Dawe CJ (1977) Pathologic anatomy of pseudobranch tumors in Pacific cod, Gadus macrocephalus. J Natl Cancer Inst 59:377-398

Anonymous (1989) Methodology of fish disease surveys. ICES Coop Res Rep 166

Banning $P$ van (1987) Long-term recording of some fish diseases using general fishery research surveys in the southeast part of the North Sea. Dis Aquat Org 3:1-11

Brooks RE, McArn GE, Wellings SR (1969) Ultrastructural observations on an unidentified cell type found in epidermal tumors of flounders. J Nat Cancer Inst 43:97-109

Bucke D, Norton MG, Rolfe MS (1983) The field assessment of effects of dumping wastes at sea: II. Epidermal lesions and abnormalities of fish in the outer Thames Estuary. Fish Res Tech Rep 72:1-16

Bucke D, Vethaak AD, Lang T, Mellergaard S (1996) Common diseases and parasites of fish in the North Atlantic: training guide for identifıcation. Tech Mar Environ Sci 19

Responsible Subject Editor: N. Peters, Hamburg, Germany
Campana SE (1982) Mortality of starry flounder (Platichthys stellatus) with skin tumors. Can J Fish Aquat Sci 40: 200-207

Dawe CJ, Bagshaw J, Poore CM (1979) Amebic pseudotumors in pseudobranchs in Pacific cod (Gadus macrocephalus). Proc Am Ass Cancer Res 20:245

Dean AD, Dean JA, Burton AH, Dicker RC (1990) Epi Info, version 5: a word processing, database and statıstics programme for epidemiology on micro-computers. USD, Stone Mountain, GA

Dethlefsen V (1984) Diseases in North Sea fishes. Helgoländer Meeresunters 37:353-374

Diamant A, McVicar AH (1987) The effect of internal and external $X$-cell lesions on common dab, Limanda Limanda $\mathrm{L}$. Aquaculture 67:127-133

Diamant A, McVicar AH (1989) Distribution of X-cell disease in common dab, Limanda limanda L., in the North Sea, and ultrastructural observations of previously undescribed developmenta! stages. J Fish Dis 12:25 37

Harshbarger JC (1984) Pseudoneoplasms in ectothermic animals. Natl Cancer Inst Monogr 65:251-273

Knust R, Dethlefsen V (1986) X-cells in gills of North Sea dab (Limanda limanda L.), epizootiology and impact on condition. Arch FishWiss 37:11-24

Martin SW, Meek AH, Willeberg P (1987) Veterinary epidemiology. Iowa State University Press, Ames

McVicar AH, Bruno DW, Fraser CO (1988) Fish diseases in the North Sea in relation to sewage sludge dumping. Mar Pollut Bull 19:169-173

McVicar AH, Bucke D, Watermann B, Dethlefsen V (1987) Gill X-cell lesion of dab Limanda limanda in the North Sea. Dis Aquat Org 2:197-204

Mellergaard S, Nielsen E (1984) Preliminary investigations on the eastern North Sea and the Skagerrak dab (Limanda limanda) populations and their diseases. Comm Meet Int Coun Explor Sea CM-ICES E: 28

Moller H (1981) Fish diseases in German and Danish coastal waters in summer 1980. Meeresforsch 29:1-16

Möller H, Anders K (1983) Diseases and parasites of marine fishes. Verlag Möller, Kiel

Morrison CM, Shum G, Appy RG, Odense P, Annand C (1982) Histology and prevalence of X-cell lesions in Atlantic cod (Gadus morhua). Can J Fish Aquat Sci 39:1519-1530

Peters N, Peters G, Stich HF, Acton AB, Bresching G (1978) On differences in skin tumours of Pacific and Atlantic flatfish. J Fish Dis 1:3-25

Peters N, Watermann B (1979) Three types of skin papillomas of flatfishes and their causes. Mar Ecol Prog Ser 1:269-276

Watermann B, Dethlefsen V (1982) Histology of pseudobranchial tumours in Atlantic cod (Gadus morhua) from the North Sea and the Baltic Sea. Helgoländer Meeresunters $35: 231$ - -242

Zar JH (1984) Biostatistical analysis. Prentice Hall, Englewood Cliffs, NJ

Manuscript first received: June 12, 1995

Revised version accepted: November 9,1995 